\title{
TOXICITY OF SUNSET YELLOW FCF AND TARTRAZINE DYES ON DNA AND CELL CYCLE OF LIVER AND KIDNEYS OF THE CHICK EMBRYO: THE ALLEVIATIVE EFFECTS OF CURCUMIN
}

\author{
Hend T. El-Borm*; Gamal M. Badawy; Sobhy Hassab El-Nabi; \\ Wessam A. El-Sherif; Marwa N. Atallah
}

Zoology Department, Faculty of Science, Menoufia University, Menoufia, Egypt

\begin{abstract}
Article History:

Received: 8 September 2020

Revised: 5 October 2020

Accepted: 6 October 2020

Published Online:

8 October 2020

\author{
Keywords: \\ Apoptosis \\ Cell cycle \\ Chick embryo \\ Curcumin \\ Synthetic food colorants \\ *Correspondence: \\ Hend El-Borm \\ Zoology Department \\ Faculty of Science \\ Menoufia University \\ Menoufia, Egypt \\ E-mail: \\ Hendtarek98@yahoo.com
}

Recently, the use of synthetic food coloring agents were widely spread; and its potential toxic effects on human health were consequently increased. The present work aimed to assess the toxicity on DNA and cytotoxicity induced by in ovo administration of synthetic food coloring agents "sunset yellow FCF and tartrazine" with/without curcumin during the organogenesis phase of chick embryo at doses $1.575 \mathrm{mg} / \mathrm{egg}$, $0.375 \mathrm{mg} / \mathrm{egg}$, and $3.0 \mathrm{mg} / \mathrm{kg}$ eggs, respectively. The results showed that sunset yellow FCF and tartrazine increased in the level of DNA damage and the percentage of apoptosis. Also, there were a pronounced $\mathrm{S}$ phase arrest and a decrease in the number of cells in the G2/M of the cell cycle in the liver and kidneys of the chick embryo treated with sunset yellow FCF and tartrazine. On the other hand, co-administration of curcumin with the synthetic food coloring agents positively alleviated the changes in DNA and cell cycle distribution, as well as decreased the apoptosis.
\end{abstract}

\section{INTRODUCTION}

Food additives are any substance either natural or synthetic that added to the food in order to improve its palatability, shelf life, and texture ${ }^{[1,2]}$. They must be added in regulated quantities and should be within the acceptable daily intake (ADI), which provides large safety margin as it is the amount of a food additive that can be consumed daily over a lifetime without any adverse effect on health ${ }^{[1]}$. According to Amin and Al-Shehri ${ }^{[3]}$, the food additive agents can be divided into preservative, flavoring, stabilizer and emulsifier, nutritional additives, and coloring agents. Food coloring is one of food additive agents that can be used in food, drugs, or cosmetics. There are two major categories of food colors; natural colors (exempt from certification) and synthetic colors (certified). It is used to offset colorless due to storage or processing of food, correct natural variation in food color, and enhance the appearance of food product to meet consumer demand ${ }^{[4]}$.

Our previous studies have shown that some food colorants as sunset yellow (SY) FCF (E110) and tartrazine (Tz) (E102) caused many histopathological changes in liver and kidney of the chick embryo ${ }^{[5]}$. In addition, skeletal and morphological malformations were also noticed in the chick embryos-treated with SY and $\mathrm{Tz}^{[6]}$. Also, 
Gupta et $a .^{[7]}$ found that erythrosine and $\mathrm{Tz}$ were teratogenic to zebrafish embryos. Moreover, some of food additives were proved to induce DNA damage in bacteria, fungi, insects, and mammalian cells in vivo and in vitro. They also cause chromosomal aberrations including mammalian cells ${ }^{[8]}$. Moreover, some of them caused DNA damage in vitro in human germ cells ${ }^{[9]}$.

SY is a synthetic azo-dye, water-soluble, and orange-red colored powder that has been used in pharmaceuticals, cosmetics, and food industry field $^{[10-12]}$. Joint FAO/WHO Expert Committee on Food Additives (JECFA) has established the maximum permitted level of SY for different types of food; the permissible limit of SY is $300 \mathrm{mg} / \mathrm{kg}$ food. Whereas, for water-based flavored drinks, the safety limit allowed is $100 \mathrm{mg} / \mathrm{kg}$ drink $^{[13]}$. The potential adverse effect of SY on human health is due to aromatic ring and azo-functional groups $(-\mathrm{N}=\mathrm{N}-)$ in their structures, as it broken down by intestinal azo-reduction and most of dose is excreted in the feces and urine, and only little amount of it will be absorbed in gastrointestinal $\operatorname{tract}^{[10,13]}$.

$\mathrm{Tz}$ is a synthetic organic azo dye, which made from petroleum products. It used in human food and drink, pharmaceutical products and cosmetics ${ }^{[14-16]}$. The JECFA evaluated ADI to be $0.0-7.5 \mathrm{mg} / \mathrm{kg} / \mathrm{day}^{[14,17]}$. $\mathrm{Tz}$ can also be used in cotton candy, soups, jelly, ice cream, jam, sauces, hair products, and medical products like vitamins, antacids, and medical capsule ${ }^{[16,18]}$. $\mathrm{Tz}$ is metabolized by the intestinal microflora into sulfanilic acid and aminopyrazolonemetabolites, which generate reactive oxygen species (ROS) leading to oxidative stress ${ }^{[15-}$ ${ }^{17]}$. Oxidative stress or generation of ROS has been closely linked to apoptosis ${ }^{[19]}$.

Curcumin (Cur) (E100) or natural yellow 3 can be used as natural food coloring agent and the major yellow pigment extracted from turmeric. Turmeric derived from the rhizomes of Curcuma longa family Zingiberaceae $^{[20]}$. The major constituents of turmeric rhizomes are volatile oils and curcuminoids. The latter composed of curcumin [1,7-bis(4-hydroxy-3-methoxyphenyl)-1,6-heptadiene-3,5-dione] (77\%), dimethoxy-curcumin (17\%), and bisdemethoxy-curcumin $(3 \%)^{[21]}$. It is a safe nutritional dietary supplement that has been widely used in traditional medicine and as a spice, coloring agent ${ }^{[22]}$. The JECFA allocated an ADI of Cur is $0.0-3.0 \mathrm{mg} / \mathrm{kg}$ body weight/day ${ }^{[23,24]}$. It is well documented fact that Cur has multiple activities such as ROS inhibitory, anti-inflammatory, antiapoptosis, antibacterial, and anticancer ${ }^{[25-27]}$.

Cur displays a pivotal role in diseases cure due to its effective scavenger to different forms of free radicals. It suppressed the generation of ROS and protected against DNA damage induced by benz(a)pyren or $\mathrm{H}_{2} \mathrm{O}_{2}{ }^{[28-30]}$. Also, Cur has alleviative effect against the genotoxicity of betamethasone in the kidney and liver tissue of both rat mothers and their fetuses ${ }^{[31,32]}$. The present study was performed to delineate the genotoxic and cytotoxic effect of two synthetic food coloring agents namely SY and $\mathrm{Tz}$ on the development of chick embryo, and to evaluate the efficiency of one natural color namely Cur in alleviating this toxicity.

\section{MATERIAL AND METHODS \\ Coloring agents' administration}

SY FCF (E110) and Tz FD\&C yellow n ${ }^{\circ} 5$ (E102) pure powders were obtained from Kamina Co. (Cairo, Egypt). Both coloring agents ( $\mathrm{SY}$ and $\mathrm{Tz}$ ) were dissolved in sterile water and injected in ovo (into the air sac) as single dose $(0.2 \mathrm{~mL} / \mathrm{egg})$ at the $6^{\text {th }}$ day of incubation; the holes were carefully sealed with molten paraffin wax.

\section{Water extraction of Cur}

Dry rhizomes of the plant (Curcuma longa) were bought from a herbal store at Shebeen El-Koom, Menoufia, Egypt and crushed into powder; $125 \mathrm{~g}$ of the powder were macerated in $1000 \mathrm{~mL}$ of sterile water for 12 hours at room temperature and filtered through a $5 \mu \mathrm{m}$ filter paper. The concentration of obtained extract was $24 \mathrm{mg} / \mathrm{mL}^{[33]}$. Cur extract was applied at a dose of $3 \mathrm{mg} / \mathrm{kg}$ $\operatorname{eggs}^{[24]}$. At the $6^{\text {th }}$ day of incubation, $0.2 \mathrm{~mL}$ 
of fluid was injected as single dose into the air sac; the holes were carefully sealed with molten paraffin wax.

\section{Egg incubation and grouping}

Principles of animal care and use were carefully followed during conducting the present study according to the guide for the care and use of laboratory animals approved by the Faculty of Science, Menoufia University, Egypt (Approval No. MNSE2208) and according to the National Institutes of Health guide for the care and use of laboratory animals (NIH publications No. 8023, revised 1978). Fresh fertilized chicken eggs (Gallus domesticus) were obtained from a local hatchery at Menouf, Menoufia governorate. Before incubation at $37^{\circ} \mathrm{C}$ in an artificial incubator, eggs were cleaned with distilled water and $70 \%$ ethanol (weighed $50 \pm 5 \mathrm{~g}$ ) and then labeled. To ensure the relevant humidity (65\%), an open one liter container filled with distilled water was placed at the bottom of the incubator. The eggs were put horizontally and turned over, at least three times a day. Eggs were candled at the second day of incubation and the un-fertilized eggs were excluded. The remaining eggs were divided into seven groups (40 eggs/each group) and injected at the six day of incubation with a single dose, which is equivalent to 14 times ADI for synthetic colorants SY and Tz. A total of 280 fertilized eggs were used as follows:

- Group (A) was not subjected to any injection (control group).

- Group (B) was injected in ovo with $0.2 \mathrm{~mL}$ of sterile water (sham group).

- Group (C) was injected in ovo with $0.2 \mathrm{~mL}$ of Cur extract at a dose of $3 \mathrm{mg} / \mathrm{kg} \mathrm{eggs}{ }^{[24]}$.

- Group (D) was injected in ovo with $0.2 \mathrm{~mL}$ of $\mathrm{SY}$ at a dose of $1.575 \mathrm{mg} / \mathrm{egg}$ $(\mathrm{ADI})^{[34]}$.

- Group (E) was injected in ovo with $0.2 \mathrm{~mL}$ of $\mathrm{Tz}$ at a dose of $0.375 \mathrm{mg} / \mathrm{egg}$ $(\mathrm{ADI})^{[14]}$.

- Group (F) was injected in ovo with $0.2 \mathrm{~mL}$ of $1: 1$ mixture of Cur extract and SY at the same above doses.
- Group (G) was injected in ovo with $0.2 \mathrm{~mL}$ of $1: 1$ mixture of Cur extract and $\mathrm{Tz}$ at the same above doses.

\section{Embryo collection}

At the $20^{\text {th }}$ day of incubation, the egg shells were broken with a scalpel and embryos were carefully freed. The living embryos were anaesthetized by light diethyl ether and dissected, and the target organs (liver and kidney) were immediately removed for subsequent analysis.

\section{Determination of DNA fragmentation}

Fresh liver and kidney samples (6 tissue samples/each group, each tissue sample weighing $10 \mathrm{mg}$ ) were used for nucleic acid extraction by DNA ladder detection kit according to the method originally introduced by Aljanabi and Martinez ${ }^{[35]}$ and modified by El-Garawani and Hassab El$\mathrm{Nabi}^{[36]}$, in which the ethidium bromide direct staining of DNA samples were done. The collected DNA samples were frozen at $-80^{\circ} \mathrm{C}$ until electrophoresed in $1.2 \%$ agarose gel to isolate DNA fragments.

\section{Cell cycle distribution analysis by flow cytometry}

Fresh tissue specimens (liver and kidney, 6 samples/each group) were transported to the laboratory of Center of Excellence in Cancer Research, Tanta University (Gharbia, Egypt) and prepared according to Tribukasit et $a l .{ }^{[37]}$ for apoptotic assays by flow cytometry. Apoptosis was measured by using the sub-G1 peak staining with propidium iodide ${ }^{[38]}$, and data analysis was conducted using BD FACS DIVA ${ }^{\text {TM }}$ software (BD Biosciences, San Jose, CA, USA), as shown in Figure 1.

\section{Data evaluation and statistical analysis}

All data sets were expressed as mean \pm standard error of the mean. The data were statistically analyzed for normal distribution (independent samples $t$ test) and homogeneity of variances (Levene's test) using statistical package of social sciences (IBM SPSS) statistics software for windows, 
Version 22 (IBM corp., Armonk, NY, USA). Differences were considered insignificant whenever $P>0.05$. The significances of the obtained data were classified into three categories, i.e. $P<0.001, P<0.01$ and $P<0.05$ according to the obtained $P$ values.
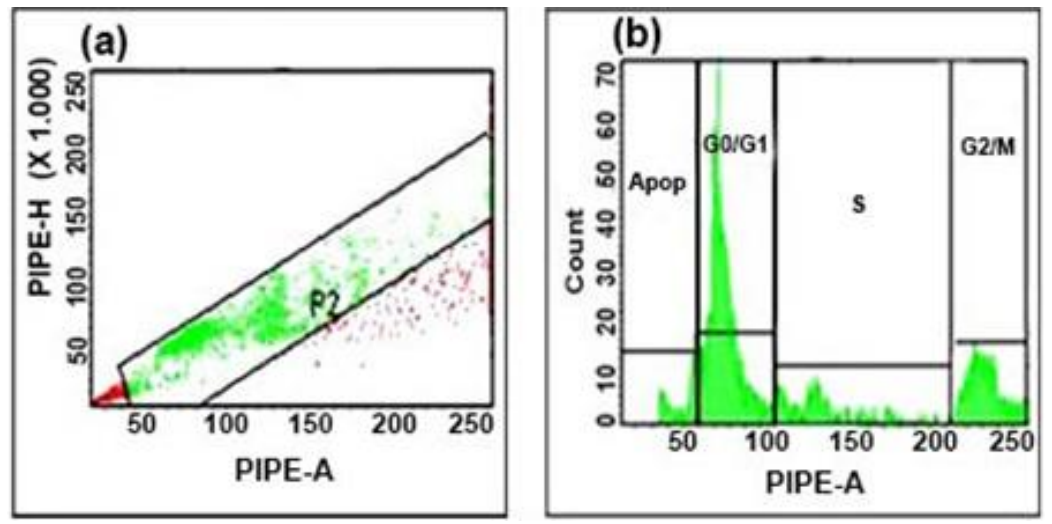

Figure 1: Representative data for apoptosis and cell cycle analysis using flow cytometry: (a) Dot plots; (b) DNA histograms. PI: propidium iodide, Apop: apoptotic cells.

\section{RESULTS}

Curcumin alleviated the DNA fragmentation in hepatic and renal tissues of SYand Tz-treated Chick embryo

Figures " $2 a$ and $2 b$ " revealed that the extracted total genomic DNA of the liver and renal cells of the control group was intact as seen in lane 1, with no damage of DNA. Also, administration of single dose of distilled water and Cur during organogenesis phase of chick embryo had no effect on the liver and renal DNA, as seen in Figure 2 (lanes 2 and 3, respectively). While, liver and renal cells of $\mathrm{SY}$ and $\mathrm{Tz}$ injected embryos showed marked DNA damage by the migration of DNA fragments, as seen in Figure 2 (lanes 4 and 5, respectively), compared with the control and sham groups (lanes 1 and 2, respectively). The liver and renal cells of $\mathrm{SY}+\mathrm{Cur}$ and $\mathrm{Tz}+\mathrm{Cur}$ treated groups showed some DNA fragmentation, but less than those of SY and Tz treated groups, as seen in Figure 2 (lanes 6 and 7, respectively).

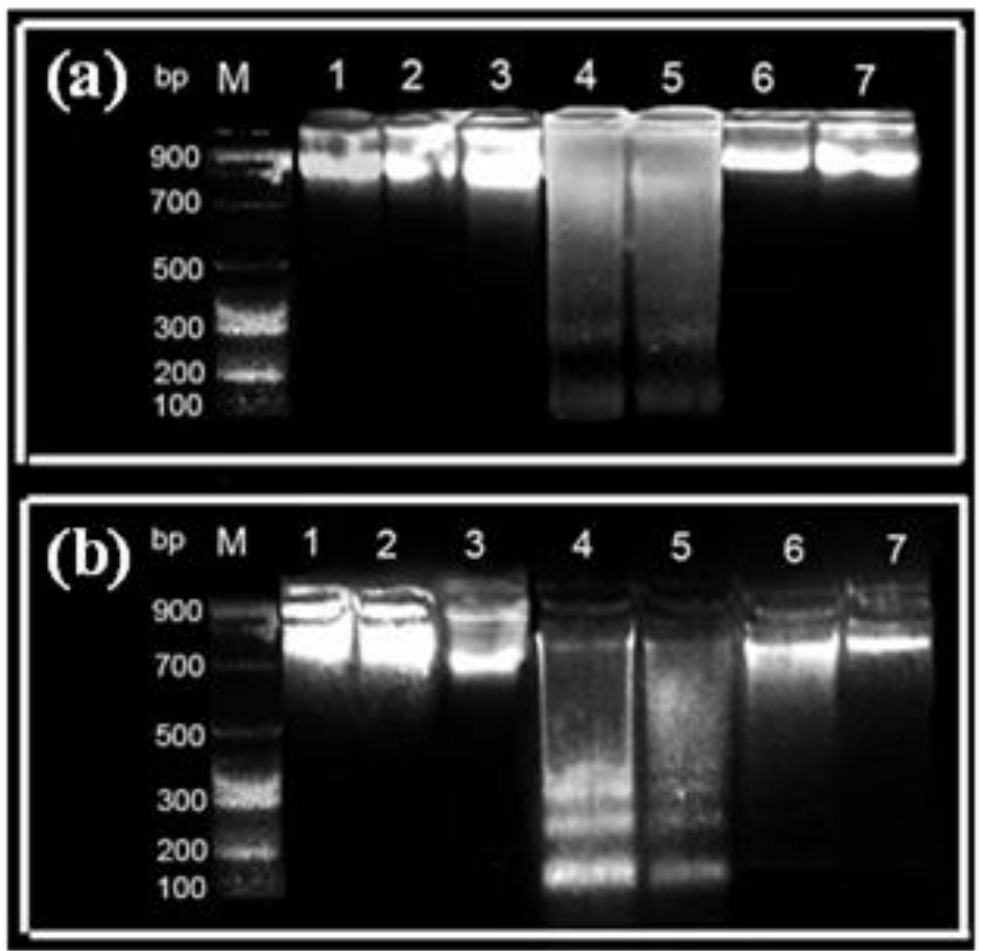

Figure 2: Photomicrographs of agarose gels showing evident variations of the DNA fragmentation in the liver (a) and kidney (b) tissue extracts of 20-days-old chick embryos treated with sunset yellow FCF and tartrazine with/without curcumin. Photo represented 6 samples/group. bp: base pair, M: marker DNA (100 bp DNA Ladder, New England Bio-labs, Ipswich, MA, USA), 1: control, 2: sham, 3: curcumin, 4: sunset yellow FCF, 5: tartrazine, 6: sunset yellow FCF+curcumin, 7: tartrazine+curcumin. 
Curcumin alleviated the apoptosis and improved the cell cycle in hepatic and renal tissues of SY- and Tz-treated Chick embryo

The percentage of liver apoptotic cells of Cur group decreased significantly $(P<0.05)$ compared with the control and sham groups $(5.60 \pm 0.05,6.00 \pm 0.09$, $2.25 \pm 0.10$, respectively, Figure 3). On the other hand, the percentage of liver apoptotic cells in groups treated with $\mathrm{SY}$ or $\mathrm{Tz}$ increased significantly $(P<0.001)$ up to $29.13 \pm 0.10$ and $31.90 \pm 0.09$, respectively, compared with the control group (Figure 3). While, co-administration of Cur with SY or $\mathrm{Tz}$ decreased significantly the percentage of liver apoptotic cells (up to 2.13 \pm 0.08 , $3.00 \pm 0.08$, respectively) compared with $\mathrm{SY}$ or $\mathrm{Tz}$ treated groups that not received Cur $(P<0.001)$ and the control group $(P<0.05)$, as shown in Figure 3. In the control group, the majority of liver cells were in G0/G1phase (Table 1). Meanwhile, in the liver cells of SY and Tz treated groups, a significant increase $(P<0.001)$ in cells of $\mathrm{S}$ phase was observed, which coincided with a significant decrease in cells of G0/G1 and $\mathrm{G} 2 / \mathrm{M}$ phases $(P<0.001)$ compared with the control group (Table 1). By comparing the results of $\mathrm{SY}+\mathrm{Cur}$ and $\mathrm{Tz}+\mathrm{Cur}$ treated groups with those of $\mathrm{SY}$ or $\mathrm{Tz}$ alone treated groups, a statistically significant lower amount of $\mathrm{S}$ phase cells $(P<0.001)$ was observed, while the percentages of cells in $\mathrm{G} 0 / \mathrm{G} 1$ and $\mathrm{G} 2 / \mathrm{M}$ phases were significantly increased $(P<0.001$, Table 1$)$.

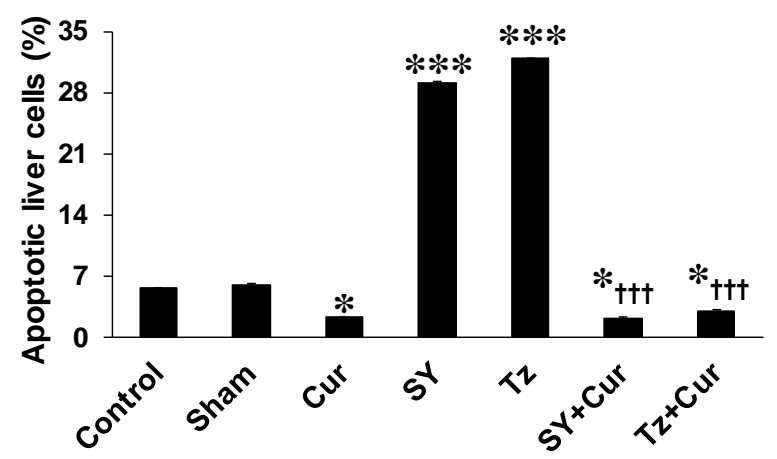

Figure 3: Percentage of apoptotic liver cells of 20-days old chick embryos treated with sunset yellow FCF and tartrazine with/without curcumin. Data are represented as mean \pm standard error of the mean $(n=6)$. Cur: curcumin, SY: sunset yellow FCF, Tz: tartrazine. $*$ and ***: $P<0.05$ and $P<0.001$, respectively, compared with the control group; $\mathrm{tt}: P<0.001$ compared with $\mathrm{SY}$ or $\mathrm{Tz}$ groups.

Table 1: Phases of liver cell cycle of 20-days old chick embryos treated with sunset yellow FCF and tartrazine with/without curcumin.

\begin{tabular}{llll}
\hline \multirow{2}{*}{ Groups } & \multicolumn{3}{c}{ Cell cycle phases } \\
\cline { 2 - 4 } & G1 & S & G2M \\
\hline Control & $63.93 \pm 0.07$ & $20.88 \pm 0.08$ & $29.62 \pm 0.05$ \\
Sham & $61.00 \pm 0.11$ & $19.93 \pm 0.08$ & $27.05 \pm 0.09$ \\
Cur & $59.10 \pm 0.29$ & $18.00 \pm 0.11$ & $27.00 \pm 0.06$ \\
SY & $6.80 \pm 0.09 * * *$ & $60.15 \pm 0.10 * * *$ & $15.00 \pm 0.06 * * *$ \\
Tz & $3.83 \pm 0.08 * * *$ & $57.02 \pm 0.06 * * *$ & $9.65 \pm 0.04 * * *$ \\
SY+Cur & $49.00 \pm 0.06 * *+t \dagger$ & $22.25 \pm 0.13 *+t \dagger$ & $19.05 \pm 0.12 * *+t \dagger$ \\
Tz+Cur & $41.90 \pm 0.09 * *+t \dagger$ & $21.93 \pm 0.07 *+t \dagger$ & $17.63 \pm 0.08 * *+t \dagger$ \\
\hline
\end{tabular}

Data are represented as mean \pm standard error of the mean $(n=6)$. Cur: curcumin, SY: sunset yellow FCF, Tz: tartrazine. *, ** and ***: $P<0.05, P<0.01$, and $P<0.001$, respectively, compared with the control group; ttt: $P<0.001$ compared with SY or Tz groups. 
There were a significant increase $(P<0.001)$ in the percentage of renal apoptotic cells in $\mathrm{SY}$ and $\mathrm{Tz}$ treated groups when compared with the control group (Figure 4). Co-administration of Cur with $\mathrm{SY}$ and $\mathrm{Tz}$ decreased significantly the percentage of renal apoptotic cells $(P<0.001$, compared with SY and $\mathrm{Tz}$ treated groups that not received Cur) up to the control values (Figure 4). In the control group, also the majority of renal cells were in G0/G1phase (Table 2). However, groups treated with $\mathrm{SY}$ and $\mathrm{Tz}$ resulted in a higher percentage of arrested cells in the $S$ phase $(P<0.001)$, which coincides with a lower percentage of cells in $\mathrm{G} 0 / \mathrm{G} 1$ and $\mathrm{G} 2 / \mathrm{M}$ phases $(P<0.001)$, compared with the control group (Table 2). Co-administration of SY or $\mathrm{Tz}$ in presence of Cur during the organogenesis phase of chick embryo displayed an evident ameliorative effect on cell cycle phases of the renal cells. In SY+Cur and $\mathrm{Tz}+\mathrm{Cur}$ treated groups, a statistically significant decrease of $\mathrm{S}$ phase arrested cells $(P<0.001)$ was observed with a significant increase in percentage of cells in $\mathrm{G} 0 / \mathrm{G} 1$ and $\mathrm{G} 2 / \mathrm{M}$ phases $(P<0.001)$ compared with those of $\mathrm{SY}$ or $\mathrm{Tz}$ alone treated groups (Table 2).

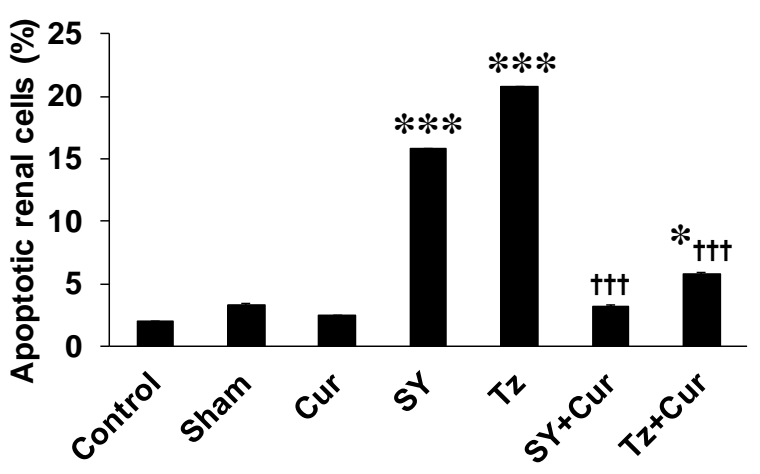

Figure 4: Percentage of apoptotic renal cells of 20-days old chick embryos treated with sunset yellow FCF and tartrazine with/without curcumin. Data are represented as mean \pm standard error of the mean $(n=6)$. Cur: curcumin, SY: sunset yellow FCF, Tz: tartrazine. $* * *: P<0.001$, compared with the control group; t†t: $P<0.001$ compared with SY or Tz groups.

Table 2: Phases of renal cell cycle of 20-days old chick embryos treated with sunset yellow FCF and tartrazine with/without curcumin.

\begin{tabular}{llll}
\hline \multirow{2}{*}{ Groups } & \multicolumn{3}{c}{ Cell cycle phases } \\
\cline { 2 - 4 } & $\mathrm{G} 1$ & $\mathrm{~S}$ & $\mathrm{G} 2 \mathrm{M}$ \\
\hline Control & $58.75 \pm 0.09$ & $17.93 \pm 0.05$ & $26.08 \pm 0.13$ \\
Sham & $50.08 \pm 0.09$ & $14.83 \pm 0.09$ & $24.88 \pm 0.07$ \\
Cur & $55.05 \pm 0.08$ & $14.05 \pm 0.09$ & $22.02 \pm 0.09$ \\
SY & $4.03 \pm 0.09 * * *$ & $71.08 \pm 0.09 * * *$ & $13.92 \pm 0.09 * * *$ \\
Tz & $3.90 \pm 0.04 * * *$ & $67.95 \pm 0.08 * * *$ & $11.15 \pm 0.09 * * *$ \\
SY+Cur & $17.95 \pm 0.05 * *+\dagger \dagger$ & $11.27 \pm 0.09 *+\dagger \dagger$ & $9.93 \pm 0.07 * * * \dagger+\dagger$ \\
Tz+Cur & $22.03 \pm 0.08 * *+\dagger \dagger$ & $15.88 \pm 0.07 *+\dagger \dagger$ & $10.82 \pm 0.11 * * * \dagger \dagger \dagger$ \\
\hline
\end{tabular}

Data are represented as mean \pm standard error of the mean $(\mathrm{n}=6)$. Cur: curcumin, SY: sunset yellow FCF, Tz: tartrazine. *, ** and ***: $P<0.05, P<0.01$, and $P<0.001$, respectively, compared with the control group; $\mathrm{t \dagger}^{\dagger}: P<0.001$ compared with $\mathrm{SY}$ or Tz groups.

\section{DISCUSSION}

The problem of the presence of food additives in an everyday diet and their possible hazard influence on human health is still discussed. So the present study is a trial to evaluate the genotoxic and 
cytotoxic effects of two of the widely used synthetic food coloring agents. In the current study Cur did not increase DNA fragmentation in liver cells of chick embryos, while liver cells from embryos injected with $\mathrm{SY}$ or $\mathrm{Tz}$ showed a marked cellular apoptosis, as a result of DNA damage. Although apoptosis is involved in many normal biological processes, it can also be induced by chemicals. It is consider as a mechanism of programmed self-murder cell. It is described morphologically by condensation of nuclear chromatin, compacting of cytoplasmic organelles, cell shrinkage, and change at the cell surface ${ }^{[39]}$. Apoptotic cells in vivo are rapidly phagocytized, whereas in vitro rupture of the plasma membrane occurs only at late stage. Biochemically the most character of apoptotic cells were the fragmentation of DNA into oligonucleosomal fragments with lengths, which are multiples of 180-200bp ${ }^{\text {[39] }}$ The genotoxicity of azo dye compounds is dependent on their conversion to reactive metabolites, such as frequently produced $\mathrm{N}$-acetylated forms. The activation is accomplished by acetyltransferases, which are widely distributed in animals ${ }^{[8,40]}$. Ali et al. ${ }^{[41]}$ also found that oral administration of mixture of SY (as coloring agent) and sodium benzoate (as a food additives) in different concentrations to female rats for 12 weeks caused DNA damage in their hepatocytes, which confirmed by different types of comet assay. In addition, Hassan ${ }^{[8]}$ reported that rats orally administrated two concentration of $\mathrm{Tz}(7.5$ and $15 \mathrm{mg} / \mathrm{kg}$ body weight/day) for 7 weeks caused DNA damage in liver cells that increased by increasing the concentration. Moreover, Chen et al. ${ }^{[42]}$ revealed that mice treated with different doses $(120,240,480 \mathrm{mg} / \mathrm{kg}$, intraperitoneally, once a week for 3 weeks) of citric acid (as food additives) caused apoptosis in hepatic cells in a dosedependent manner. The present study revealed the alleviative role of Cur against $\mathrm{SY}$ and $\mathrm{Tz}$ genotoxicity, as it reduced DNA fragmentation in hepatocytes of chick embryo. Abd-Alfattah and Abdelraouf ${ }^{[43]}$ also reported a reduction in apoptotic DNA fragmentation in hepatocytes of rats treated with $\mathrm{CCL}_{4}+\mathrm{Cur}$ comparing with DNA extracted from hepatic tissue of rats treated with $\mathrm{CCL}_{4}$ alone. In addition, Ghosh et al. ${ }^{[44]}$ revealed that Cur decreased all the streptozotocin-induced diabetic pathophysiology to male rats that induced hepatocellular apoptotic DNA fragmentation. Alhusaini et $a .^{[45]}$ reported that Cur prohibited hepatocellular DNA fragmentation induced by oral administration of $\mathrm{CuSO}_{4}$. Moreover, Madkour ${ }^{[46]}$ showed that oral administration of Cur alleviated the liver apoptotic DNA fragmentation caused by $\lambda$-cyalothrin (an insecticide) in rats.

On the other hand, renal cells of chick embryos treated with $\mathrm{SY}$ and $\mathrm{Tz}$ showed increased incidence of DNA damage. Hassan $^{[8]}$ also found that Tz induced DNA damage in kidney of rats. Also, Chen et al. ${ }^{[42]}$ indicated that citric acid (as food additives) caused apoptotic DNA fragmentation in renal tissue of mice in a dose-dependent manner. Similar genotoxic findings were obtained by Abo-EL-Sooud et al. ${ }^{[47]}$ who displayed that rats orally administrated with $\mathrm{Tz}$ at dose of $3 \mathrm{mg} / \mathrm{kg}$ body weight, daily for 60 days, caused moderate to high degree of DNA damage in renal cells. Cur was also effective in reducing the apoptotic DNA fragmentation in renal cells of chick embryos in the current study. Bayomy et $a{ }^{[48]}$ indicated that Cur inhibited the action of gentamicin-induced renal apoptosis, as result of DNA damage in renal tissue of rats. Cur also alleviated the degree of DNA fragmentation in rat fetal kidney after injection of betamethasone during organogenesis $^{[31]}$.

Cell cycle distribution analysis by flow cytometry was carried out to monitor the cell cycle progression and to study the effect of food coloring agents on both cell division and growth. Flow cytometry depends on measuring cellular DNA content for revealing the cell distribution with its phases and estimating the indecision of apoptotic cells with fraction DNA content ${ }^{[49]}$. The most clear feature of cell cycle are the 
synthesis and duplication of nuclear DNA before division, and the process of cellular division i.e. mitosis ${ }^{[50]}$. The cell cycle consists of special phases G0 phase (quiescence), G1 phase, S phase (synthetic growth phases for many RNA and protein molecules that would be needed for DNA synthesis and cell growth before division), G2 phase (an interphase that was a time for repair of any DNA damage, which had occurred during the preceding cell cycle and for reorganization of the DNA structure before the DNA division between daughters cells), and $\mathrm{M}$ phase (mitosis, which subdivided into stages called nuclear morphology $)^{[51,52]}$. The traditional flow cytometry histogram analysis identified as G0/G1, S phase, and G2/M; couldn't able to distinguish between G0 and G1 phase, or G2 and M phase ${ }^{[52]}$. The flow cytometry is able to measure the apoptosis as the cell visible as peak below G1 and usually Gaussian in shape and quantitated by histogram analysis. The present study revealed disturbance of the cell cycle and enhancement of cell death due to DNA fragmented of hepatocytes and renal cells of chick embryo among $\mathrm{SY}$ and $\mathrm{Tz}$ treated groups (cells arrested in $\mathrm{S}$ phase leading to a decrease in cellular division when compared with the control group). This is in agreement with Lye et al. ${ }^{[53]}$ who investigated the effect of three food dyes (SY, fast green FCF, and new coccin) on human liver cell line in vitro. They significantly affected the viability of cell and induced cell death. Also, Athinarayanan et al. ${ }^{[54]}$ showed that Silica E551 (as a food additives) induced a dose-dependent change in gene expression and cell cycle of human lung normal fibroblast. Meanwhile, Bhattacharyya et al. ${ }^{[55]}$ showed that Carrageenan (as a food additives) increased human IEC death in vitro and cell cycle arrest, and reduced cell proliferation. The present study demonstrated that Cur administration ameliorated the cell cycle distribution in hepatic and renal cells of SY and $\mathrm{Tz}$ treated chick embryo, as it decreased the percentage of cell death and the arresting in $S$ phase of both hepatic and renal cells compared with the control group. It was reported that Cur can inhibit the chemotherapy-induced apoptosis in models of human breast cancer through its ability to scavenger ROS and inhibit the mitochondrial release of cytochrome ${ }^{[56]}$.

In conclusion, the synthetic colorants agents i.e. SY and $\mathrm{Tz}$ induced apoptosis and disturbance of cell cycle in liver and kidney when administrated in ovo at doses $1.575 \mathrm{mg} / \mathrm{egg}$ and $0.375 \mathrm{mg} / \mathrm{egg}$, respectively, during the organogenesis phase of the chick embryo. Furthermore, Cur administration alleviated significantly these genotoxic effects of $\mathrm{SY}$ and $\mathrm{Tz}$ in chick embryo. Therefore, it is essential to be aware of the hazardous effects of food additives, especially during pregnancy, and more attention should be focused towards using natural substitutes.

\section{FUNDING SOURCE DISCLOSURE}

This study did not receive any specific grant from funding agencies in the public, commercial, or not-for-profit sectors.

\section{CONFLICT OF INTEREST}

The authors declared that they have no potential conflict of interest.

\section{REFERENCES}

[1] Aderemi, A. V.; Adelove, D. and Aderemi, M. A. (2015). Food additives and their health implications on children in Africa: a systematic review. Res J Health Sci, 3: 1-12.

[2] Paula-Neto, H. A.; Ausina, P.; Gomez, L. S. et al. (2017). Effects of food additives on immune cells as contributors to body weight gain and immune-mediated metabolic dysregulation. Front Immunol, 8: 1478 (DOI: 10.3389/fimmu.2017.01478).

[3] Amin, K. A. and Al-Shehri, F. S. (2018). Toxicological and safety assessment of tartrazine as a synthetic food additive on health biomarkers: 
a review. Afr J Biotechnol, 17(6): 139149.

[4] Visweswaran, B. and Krishnamoorhy, G. (2012). Oxidative stress by tartrazine in the testis of Wistar rats. IOSRJPBS, 2(3): 44-49.

[5] El-Borm, H. T.; Badawy, G. M.; El-Nabi, S. H. et al. (2019). Efficacy of curcumin on sunset yellow and tartrazine induced hepatotoxicity and nephrotoxicity in the chick embryo Gallus domesticus. EJPMR, 6(11): 4864.

[6] El-Borm, H. T.; Badawy, G. M.; El-Nabi, S. H. et al. (2020). The ameliorative effect of curcumin extract on the morphological and skeletal abnormalities induced by sunset yellow and tartrazine in the developing chick embryo Gallus domesticus. Heliyon, 6: e03305 (DOI: 10.1016/ j.heliyon.2020.e03305).

[7] Gupta, R.; Ranjan, S.; Yadav, A. et al. (2019). Toxic effects of food colorants erythrosine and tartrazine on zebrafish embryo development. Curr Res Nutr Food Sci, 7(3): 876-885.

[8] Hassan, G. M. (2010). Effects of some synthetic coloring additives on DNA damage and chromosomal aberrations of rats. Arab J Biotech, 13: 13-24.

[9] Pandir, D. (2016). DNA damage in human germ cell exposed to the some food additives in vitro. Cytotechnology, 68: 725-733.

[10] EFSA Panel on Food Additives and Nutrient Sources added to Food (ANS) (2009). Scientific opinion on the reevaluation of sunset yellow FCF (E110) as a food additive. EFSA Journal, 7(11): 1330 (DOI: 10.2903/j.efsa.2009. 1330).

[11] Saatloo, N. V.; Sadighara, P.; Khaniki, G. J. et al. (2015). Evaluating the interaction effects of using common synthetic food dyes and aspartame by Artemia salina toxicity test. Journal of Food Safety and Hygiene, 1: 13-17.

[12] Allam, K. V. and Kumar, G. P. (2011). Colorants - the cosmetics for the pharmaceutical dosage forms. Int $\mathbf{J}$ Pharm Pharm Sci, 3: 13-21.

[13] Rovina, K.; Acung, L. A.; Siddiquee, S. et al. (2017). Extraction and analytical methods for determination of sunset yellow (E110) - a review. Food Anal Methods, 10: 773-787.

[14] Moutinho, I. L. D.; Bertges, L. C. and Assis, R. V. C. (2007). Prolonged use of the food dye tartrazine (FD\&C yellow $\mathrm{n}^{\circ}$ ) and its effects on the gastric mucosa of Wistar rats. Braz $\mathrm{J}$ Biol, 67: 141-145.

[15] EFSA Panel on Food Additives and Nutrient Sources added to Food (ANS) (2009). Scientific opinion on the reevaluation tartrazine (E102). EFSA Journal, 7(11): 1331 (DOI: 10.2903/ j.efsa.2009.1331).

[16] Khayyat, L.; Essawy, A.; Sorour, J. et al. (2017). Tartrazine induces structural and functional aberrations and genotoxic effects in vivo. Peer J, 5: e3041 (DOI: 10.7717/peerj.3041).

[17] Himri, I.; Bellahcen, S.; Souna, F. et al. (2011). A 90-day oral toxicity study of tartrazine, a synthetic food dye, in Wistar rats. Int J Pharm Pharm Sci, 3(3): 159-169.

[18] Ghonimi, W. A. M. and Elbaz, A. (2015). Histological changes of selected Wistar rat tissue following the ingestion of tartrazine with special emphasis on the protective effect of royal jelly and cod liver oil. J Cytol Histol, 6: 346 (DOI: 10.4172/21577099.1000346).

[19] Xu, Y.; Nie, L.; Yin, Y.-G. et al. (2012). Resveratrol protects against hyperglycemia- induced oxidative damage to mitochondria by activating sirt1 in rat mesangial cells. Toxicol Appl Pharmacol, 259(3): 395-401.

[20] Rathaur, P.; Raja, W.; Ramteke, P. W. et al. (2012). Turmeric: the golden spice of life. IJPRS, 3(7): 1987-1994.

[21] Pulido-Moran, M.; Moreno-Fernandez, J.; Ramirez-Tortosa, C. et al. (2016). Curcumin and health. Molecules, 21: 
264 (DOI: 10.3390/molecules 21030264).

[22] Garcia-Nino, W. R. and PedrazaChaverri, J. (2014). Protective effect of curcumin against heavy metalsinduced liver damage. Food Chem Toxico, 69: 182-201.

[23] EFSA Panel on Food Additives and Nutrient Sources added to Food (ANS) (2010). Scientific opinion on the re-evaluation of Curcumin (E100) as a food additive. EFSA Journal, 8(9): 1679 (DOI: 10.2903/ j.efsa.2010.1679).

[24] Amalraj, A.; Pius, A.; Gopi, S. et al. (2017). Biological activities of curcuminoids, other biomolecules from turmeric and their derivatives a review. J Tradit Complement Med, 7(2): 205-233.

[25] Estakhri, M. A.; Shokrzadeh, M.; Jaafari, M. R. et al. (2019). Organ toxicity attenuation by nanomicelles containing curcuminoids: comparing the protective effects on tissues oxidative damage induced by diazinon. Iran J Basic Med Sci, 22: 17-24.

[26] Pricci, M.; Girardi, B.; Giorgio, F. et al. (2020). Curcumin and colorectal cancer: from basic to clinical evidences. Int J Mol Sci, 21(7): 2364 (DOI: 10.3390/ijms21072364).

[27] Stohs, S. J.; Chen, O.; Ray, S. D. et al. (2020). Highly bioavailable forms of curcumin and promising avenues for curcumin-based research and application: a review. Molecules, 25(6): 1397 (DOI: 10.3390/molecules 25061397).

[28] Ismail, M. A. and Sakr, S. M. (2016). Validation of replacement of the synthetic food dye 'sunset yellow'induced hepatotoxicity and genotoxicity with the nutraceutical 'curcumin' in mice. Merit Res J Med Med Sci, 4: 025-050.

[29] Hewlings, S. J. and Kalman, D. S. (2017). Curcumin: a review of its effects on human health. Foods, 6(10): 92 (DOI: 10.3390/foods6100092).
[30] Jovičić, D.; Jozinović, A.; Grčević, M. et al. (2017). Nutritional and health benefits of curcumin. Food in Health and Disease, Scientific-Professional Journal of Nutrition and Dietetics, 6: 22-27.

[31] Badawy, G. M.; Sakr, S. A. and El-Borm, H. T. (2016). The ameliorative role of curcumin administration against betamethasoneinduced maternal and fetal nephrotoxicity in rats. EJPMR, 3(6): 123-136.

[32] Badawy, G. M.; Sakr, S. A. and El-Borm, H. T. (2017). The ameliorative role of curcumin administration against betamethasoneinduced maternal and fetal hepatotoxicity in rats. JBSAR, 3(2): 118-130.

[33] Kamtchouing, P.; Mbongue Fandio, G. Y.; Dimo, T. et al. (2002). Evaluation of androgenic activity of Zingiber officinale and Pentadiplandra brazzanae in male rats. Asian J Androl, 4(4): 299-301.

[34] Hashem, M. M.; Atta, A. H.; Arbid M. S. et al. (2011). Toxicological impact of amaranth, sunset yellow and curcumin as food coloring agents in albino rats. J Pioneer Med Sci, 1(2): 43-51.

[35] Aljanabi, S. M. and Martinez I. (1997). Universal and rapid salt-extraction of high quality genomic DNA for PCR-based techniques. Nucleic Acids Research, 25(22): 4692-4693.

[36] El-Garawani, I. M. and Hassab El-Nabi, S. E. (2016). Increased sensitivity of apoptosis detection using direct DNA staining method and integration of acridine orange as an alternative safer fluorescent dye in agarose gel electrophoresis and micronucleus test. CJPAS, 10(2): 3865-3871.

[37] Tribukasit B.; Moberger, G. and Zetterberg, A. (1975). Methodological aspects of rapid-flow cytoflurometry for DNA analysis of human urinary bladder cells. In: Pulse Cytophotometry, Part 1 (Haenen, 
C.; Hillen, H. and Wessels, S., eds), pp. 55-60. European Press Medicon, Ghent, Belgium.

[38] Cohen, J. J. and Al-Rubeai, M. (1995). Apoptosis-targeted therapies: the 'next big thing' in biotechnology? Trends Biotechnol, 13: 281-283.

[39] Guicciardi, M. E.; Malhi, H.; Mott, J. L. et al. (2013). Apoptosis and necrosis in the liver. Compr Physiol, 3(2): 977-1010.

[40] Tsuda, S.; Murakami, M.; Matsusaka, N. et al. (2001). DNA damage induced by red food dyes orally administrated to pregnant and male mice. Toxicol Sci, 61: 92-99.

[41] Ali, M. Y.; Hassan, G. M.; Hassan, A. M. S. et al. (2018). In vivo genotoxicity assessment of sunset yellow and sodium benzoate in female rats. Drug Chem Toxicol, 43(5): 504513.

[42] Chen, X.; Lv, Q.; Liu, Y. et al. (2014). Study on injury effect of food additive citric acid on liver tissue in mice. Cytotechnology, 66(2): 275-282.

[43] Abd-Alfattah, A. A. and Abdelraouf, Y. M. (2018). Study the effect of curcumin on hepatic DNA damage in an experimental model of hepatic fibrosis. Bull Egypt Soc Physiol Sci, 38(2): 100-110.

[44] Ghosh, S.; Bhattacharyya, S.; Rashid, K. et al. (2015). Curcumin protects rat liver from streptozotocin-induced diabetic pathophysiology by counteracting reactive oxygen species and inhibiting the activation of p53 and MAPKs mediated stress response pathways. Toxicol Rep, 2: 365-376.

[45] Alhusaini, A.; Fadda, L.; Hassan, I. et al. (2018). Liposomal curcumin attenuates the incidence of oxidative stress, inflammation, and DNA damage induced by copper sulfate in rat liver. Dose response, 16(3): 1559325818790869 (DOI: 10.1177/ 1559325818790869).

[46] Madkour, N. K. (2012). Protective effect of curcumin on oxidative stress and DNA fragmentation against lambda cyhalothrin-induced liver damage in rats. J Appl Pharm Sci, 2(12): 076-081.

[47] Abo-El-Sooud, K.; Hashem, M. M.; Badr, Y. A. et al. (2018). Assessment of hepato-renal damage and genotoxicity induced by long-term exposure to five permitted food additives in rats. Enviro Sci pollut Res Int, 25(26): 26341-26350.

[48] Bayomy, M. F. F.; Hasab El-Nabi, S. E.; Salem, T. A. et al. (2011). Protective role of curcumin on gentamicin induced renal toxicity in male albino rats. Egypt J Exp Biol (Zool), 7: 63-69.

[49] Darzynkiewicz, Z.; Huang, X. and Zhao, H. (2017). Analysis of cellular DNA content by flow cytometry. Curr Protoc Cytom, 82: 7.5.1-7.5.20.

[50] Cobb, L. and Das, S. (2013). The cell cycle analysis. Mater Methods, 3: 172 (DOI: 10.13070/mm.en.3.172).

[51] Tabll, A. and Ismail, H. (2011). The use of flow cytometric DNA ploidy analysis of liver biopsies in liver cirrhosis and hepatocellular carcinoma. In: Liver Biopsy (Takahashi, H., ed), pp. 87-108. IntechOpen Limited, London, UK.

[52] Qiu, L.; Liu, M. and Pan, K. (2013). A triple staining method for accurate cell cycle analysis using multiparameter flow cytometry. Molecules, 18(12): 15412-15421.

[53] Lye, H. M.; Chiew, J. C. and Siddigue, M. M. (2018). Cytotoxic effect of commonly used food dyes on human hepatoma cell line HepG2. IFRJ, 25(4): 1457-1463.

[54] Athinarayanan, J.; Periasamy, V. S.; Alsaif, M. A. et al. (2014). Presence of nanosilica (E551) in commercial food products: TNF-mediated oxidative stress and altered cell cycle progression in human lung fibroblast cells. Cell Biol Toxicol, 30(2): 89-100.

[55] Bhattacharyya, S.; Borthakur, A.; Dudeja, P. K. et al. (2008). Carra- 
geenan induces cell cycle arrest in human intestinal epithelial cells in vitro. J Nutr, 138(3): 469-475.

[56] Somasundaram, S.; Edmund, N. A.; Moore, D. T. et al. (2002). Dietary curcumin inhibits chemotherapy apoptosis in models of human breast cancer. Cancer Res, 62(13): 38683875 .

\section{How to cite this article:}

El-Borm, H. T.; Badawy, G. M.; Hassab El-Nabi, S.; El-Sherif, W. A. and Atallah, M. N. (2020). Toxicity of sunset yellow FCF and tartrazine dyes on DNA and cell cycle of liver and kidneys of the chick embryo: the alleviative effects of curcumin. Egyptian Journal of Zoology, 74: 43-55 (DOI: 10.12816/ejz.2020.42218.1040). 


\section{سُمية صبغتي الأصفرغروبي والتارترازين على الحمض النووي ودورة الخلية في كبد وكُلى جنين الاجاج: التأثيرات المخفقِة للكوركومين النورين}

هند طارق البرم، جمال متولي بلوي، صبحي حسب النبي، وسام أحمد الثريف، مروه نبيل عطا الله

قسم علم الحيوان، كلية العلوم، جامعة المنوفية، المنوفية، جمهورية مصر العربية

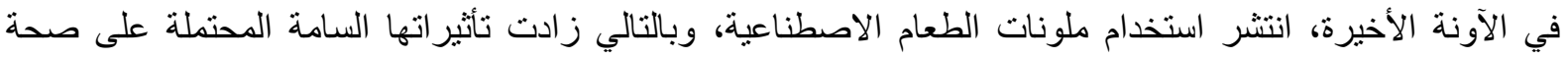

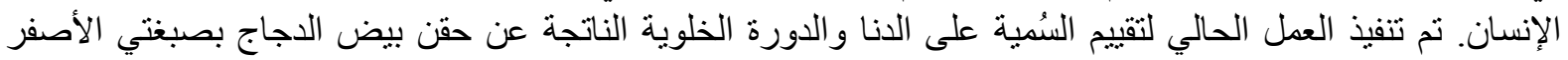

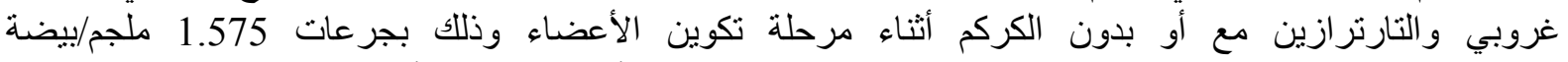

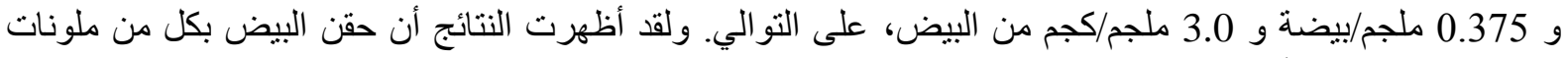

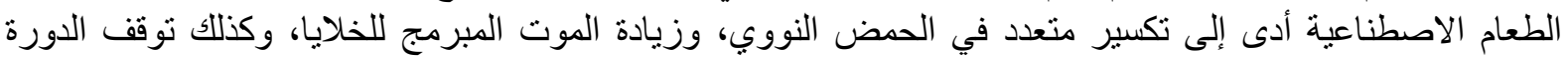

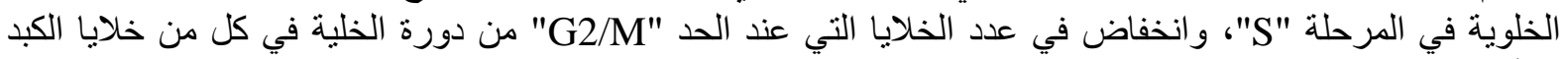

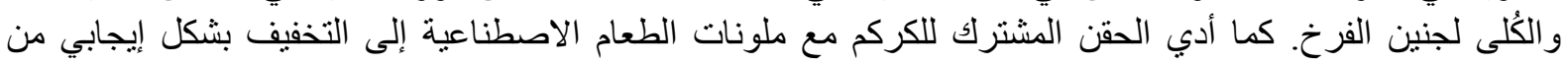

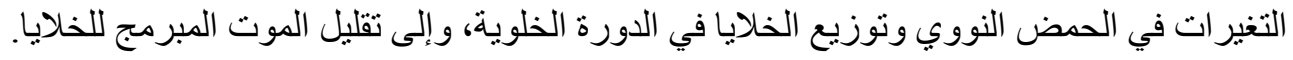

